\title{
What could scientists do about 'post-truth'?
} The Oxford English Dictionary's Word of the Year for 2016 is 'post-truth',
which they say is:

an adjective defined as 'relating to or denoting circumstances in which objective facts are less influential in shaping public opinion than appeals to emotion and personal belief',

to which they add this example:

In this era of post-truth politics, it is easy to cherrypick data and come to whatever conclusion you desire.

A recent article in the Economist points out that politicians have lied for as long as there has been formal politics and politicians. Few would disagree that scientists have lied (or dissembled or misled) for as long as there has been codified science. Whether in the form of prevailing, dominant ideology (for example, the sun goes around the earth and Lysenkoism) or personal ideology (vaccines cause autism; HIV does not lead to AIDS), science is not lacking in deceitfulness and claims made in the absence of seriously demonstrable truths.

The difference between 'dishonesty' (for whatever political or scientific end - or both, of course) and the era of 'post-truth' is, however, clear and important to understand. Dishonesty and lies are readily challenged and shown for what they are - even if belatedly and tragically, as in the case of the assertions that Iran had a vast store of weapons of mass destruction, or the claim that vaccinations cause autism. In the era of post-truth, lies are accepted as, and become, widely accepted truths with a vast majority of people, in most instances, not only accepting the truth of what is not true but propagating it and disseminating it widely. So, for example, Barack Obama is not a citizen of the USA, the South African Public Protector does not have legal authority, or the President of South Sudan is a man innocent of war crimes. These and similar clearly deniable assertions, however, are asserted and disseminated, and become widely accepted. They also become the basis for action.

The Economist put it this way:

Post-truth has also been abetted by the evolution of the media. The fragmentation of news sources has created an atomised world in which lies, rumour and gossip spread with alarming speed. Lies that are widely shared online within a network, whose members trust each other more than they trust any mainstream-media source, can quickly take on the appearance of truth. Presented with evidence that contradicts a belief that is dearly held, people have a tendency to ditch the facts first.
Sadly, the post-truth (sometimes called the 'post-factual') era has played a serious, dishonest and corrosive role in the turbulence that has come close to placing the survival of South African universities and their recognition in the international world of higher education at risk. Without trivialising the complexity of the demonstrations, some students have simply denied the economic fallacies implied in fee-free higher education, while some academics have fallen prey to the emotive rather than the demonstrable realities that have underpinned many of the issues that characterise the wide range of demands made by protesting student groups.

The implications and dangers of post-truthism are, however, much wider than those confronting South African higher education. And they are compounded by the anti-intellectual atmosphere being experienced in many parts of the world. Higher education institutions are attacked and threatened even in countries that have a democratic system and the risk is even greater in countries that do not have democratic systems.

For universities, and their academics, to counter post-truth they must have credibility, which makes the challenge a double one: to have trustworthiness, and to provide the hard data that call the lie to emotionbased beliefs.

Ole Petter Ottersen, Rector of the University of Oslo, recently wrote: 'Universities have to re-establish a respect for objective truth and powerful arguments - through our educational programmes and through our public outreach'.

To do so is not an easy task - universities have to establish, again, respect for objective truth and convincing arguments. Perhaps one of the most essential parts of the task would include respect for the process of the rigorous review of research findings in order to weed out potential deceits and dishonesties that serve to cast doubts on the academic project. But the task needs more than that. It will have to include academics being seriously engaged in public outreach and debates, and a willingness to present proven realities to counter 'post-factual' positions. An example of this is the challenge that scientists will face in order to take a stand against the views of Donald Trump's Secretary for the Environment who scoffs at the evidence for anthropogenic global warming - an undertaking that will face, additionally, the united efforts of the powerful fossil fuel industries. Closer to home, hard evidence about the dangers of fracking, and of the inappropriateness of a multibillion rand nuclear solution to our electric power needs, will be required.

Facing - and facing down - positions grounded on emotion-based fallacies is not an easy stance to assume, and will, in all likelihood, become more difficult in an increasingly populist world. Yet it is a duty that universities and their scientists cannot afford to neglect.

HOW TO CITE: Butler-Adam J. What could scientists do about 'post-truth'? S Afr J Sci. 2017;113(1/2), Art. \#a0195, 1 page. http://dx.doi.org/10.17159/ sajs.2017/a0195 